\title{
The Indian Battle Near Crescent
}

\author{
By O. J. Pruitt
}

Both historical data and folklore stories tell of an Indian battle that is said by some to have occurred in September, 1840, at about the present site of Crescent, Iowa. They do not agree in entirety, nor does archeological evidence entirely coincide. The date, probably may be nearly correct, for about that there seems to be quite general agreement. Old-timers in the vicinity often tell of the battle, and their tales do not always quite match. But, enough is known to confirm the battle having taken place, and near or on the present site of the town of Crescent, some ten miles north of Council Bluffs.

Various types of Indian burials there were described by the writer in an article appearing in the ANNaLs several years ago relating to Pottawattamie county Indian burials, including excavations of seven burial mounds by the late Dr. Gilder and assistants ${ }^{1}$ at this point. Since those "wheel" burials have relation to that incident, I will briefly describe them.

Graves containing as many as nine skeletons were uncovered showing burial head in, with extremities extending outward much like spokes of a wagon wheel. Also, a number of others were found in the river tier counties. All were very shallow, and no artifacts ever found in the graves, other than unio shells with which the graves were dug.

The archeological evidence would place the site of the battle in section 33, Boomer township, along the North Pigeon creek. Here, at various times, hundreds of artifacts have been found including many potsherds. This site later was that of the Bibee camp awaiting to join a wagon train to cross the plains to California, Utah and Oregon. This could be as late

${ }^{1}$ ANNALS OF IowA, Vol. XXV, No. 4, p. 248, July, 1944. 
as in 1852 , when the last of the Mormons decamped from this area.

The folklore tales so radically disagree in details, and the archeological evidence being indisputable, that the writer believes the imaginations of some early settlers colored their stories, which passed along from one generation to another.

As proof, many of the artifacts found in field and the north Pigeon creek are of the Algonquins and it is positive some of the shards are those of the Woodland culture, and that takes one back before Columbian days. How long has the Missouri valley been inhabited? A single tiponi stone and a few prayed sticks found in under a ground cave along with elaphus dentine only arouses one's curiosity. Various types of shards could have been made by a single tribe for only two types of binder was used, crushed deteriorating granite and clam shell. After all, the writer is a dilettante and possibly never more than 25 percent correct.

One folklore tale quite generally credited tells of thirty Pottawattamie, Ottawa and Chippewa young Indians who having been fully warned by P. J. DeSmet to keep the peace with neighboring tribes, disregarded the warning and marched on twice their number camped atop a bluff in native timber a little north and east of the village of Crescent. It was in the month of September and the wind was blowing from the southeast. It was a decided advantage to the Cherokee and Sioux. Their arrows carried farther and with more deadly effect, while the Pottawattamie had to shoot against the wind. The battle raged the greater part of the day in potshot style. Twenty-one of the Pottawattamie lay dead on the field and the remaining nine are said to have fled north across the main Pigeon creek. They were pursued and slain to the last man.

A wheel burial atop a bluff on the adjoining farm of S. B. Peters was opened by him, Uncle Joe Thomas and the writer. Here we found nine skeletons with skulls bashed in, presumably by a blunt instrument, 
a tomahawk. The dentine was that of young adult males which may well be considered to represent the nine slain as mentioned. But this is far from the truth, as the burial at that time represented great age. It could be that the real burial of the Pottawattamie was farther north and east, as all the bluffs on the north of Pigeon and North Pigeon are rolling and peaked ever and anon.

DeSmet makes no mention of this battle, but it is known that he visited the Cherokees and begged them to keep the peace and limit their hunting grounds to territory bounded on the south by the Boyer river. Crescent is some 15 or more miles south of the prescribed boundary line.

On the hillside east of the Bibee camp-site, Uncle Joe Thomas and the writer excavated the grave containing the skeleton of an adult female and an infant, thought to be the wife and child of Polk Roach, later an infamous character of Civil war days. In the timber beyond this grave are numerous Indian graves of unknown tribes. The "wheel" burials are accredited to the Winnebago, but in the burials of the dead in the outbreak of smallpox in 1848, they dug pits and burned the bodies. This work was that of Dr. R. F. Gilder of Omaha. He had as assistants Jack DeWitt, a reporter, two Omaha university students and the writer. The only feature of this was the finding of a female nether jaw containing supernumerary dentine. Otherwise our entire day spent at labor was futile.

\section{When One Talked at a Time}

In the whole history of law and order the longest step forward was taken by primitive man when, as if by common consent, the tribe sat down in a circle and allowed only one man to speak at a time.-Curtis Bok. 
Copyright of Annals of Iowa is the property of State of Iowa, by \& through the State Historical Society of Iowa and its content may not be copied or emailed to multiple sites or posted to a listserv without the copyright holder's express written permission. However, users may print, download, or email articles for individual use. 